\title{
Ensaio sobre a presença da Filosofia e poesia na canção de Noel Rosa
}

\author{
PHILOSOPHY AND POETRY IN \\ NOEL ROSA'S SONG
}

José Eduardo Costa Silva' Universidade Federal do Espirito Santo zed2004@gmail.com 


\section{Resumo}

Neste ensaio reflito sobre a presença da Filosofia e da poesia na canção de Noel Rosa. Atento-me à maneira como o compositor articula esses dois modos de posicionar a linguagem diante das necessidades de expressão e reflexão humanas. No meu entender, Noel Rosa usa a poesia para tornar a Filosofia um patrimônio cotidiano, acessível às camadas populares que ele queria ver incluídas na sociedade brasileira. Desenvolvo minha argumentação tendo como referência os próprios textos das canções, articulando-os, quando necessário, às referências filosóficas que eles sugerem, dentre tantas: Sócrates, Marx, Nietzsche, Schopenhauer, Heidegger. $O$ que se desvela como resultado desta reflexão é a visão de mais uma senda de profundidade no profícuo e criativo processo artístico que Noel Rosa nos deixou como um legado que permite o gozo e o aprendizado constantes.

Palavras Chave: Noel Rosa. Canção. Filosofia. Poesia. Cotidiano.

\section{Abstract}

In this essay I reflect on the presence of philosophy and poetry in Noel Rosa's song. I am attentive to the way in which the composer articulates these two ways of positioning language before the needs of human expression and reflection. In my opinion, Noel Rosa uses poetry to make philosophy a daily heritage, accessible to the popular strata that he wanted to see included in Brazilian society. I develop my argument based on the song texts themselves, articulating them, when necessary, with the philosophical references they suggest, among so many: Socrates, Marx, Nietzsche, Schopenhauer, Heidegger. What is revealed as a result of this reflection is the vision of another path of depth in the fruitful and creative artistic process that Noel Rosa left us as a legacy that allows for constant enjoyment and learning.

Keywords: Noel Rosa. Song. Philosophy. Poetry. Daily

\footnotetext{
1. José Eduardo Costa Silva é doutor e mestre em Música pela Universidade Federal do Estado do Rio de Janeiro (UNIRIO). Historiador e especialista em Filosofia pela Universidade Federal de Minas Gerais (UFMG). É professor associado na Universidade Federal do Espírito Santo (UFES), onde também desenvolve projetos de pesquisa em composição musical, filosofia, psicanálise, artes e linguagem. Dentre outros escritos, é autor dos livros Heidegger e a Música da Poesia (Editora Prismas, PR) e Música, Alma e Desejo: segundo os gregos (Lumme Editor, SP). Sua produção musical divide-se em registros de obras do repertório barroco e renascentista, registro e composição de música para alaúde e também para obras audiovisuais.
} 


\section{Introdução}

A opção por escrever um ensaio é deliberada, posto que, tomando a própria compreensão corrente deste gênero textual, busco deter-me na possibilidade de experimentar uma opinião, antes de tentar encontrar algum tipo de certeza dada por algum procedimento investigativo. Se me proponho a falar sobre a presença da poesia e da Filosofia na canção de Noel Rosa, parto da noção de que me enveredo pelo inseguro campo dos contextos polissêmicos, onde se cogita menos a possibilidade dos consensos sobre o que venha a significar uma coisa e mais o juízo de que aquilo que falamos foi insuficiente ou mesmo errado. Não digo tais palavras para defender-me de futuras críticas, pois, certamente, muitos têm uma leitura sobre as canções por mim comentadas e no fundo esperam que algo próximo do ainda não pronunciado, ou mesmo do completo, um dia seja dito sobre elas. Nunca será esse o caso, suponho. Não obstante, quero demarcar a posição filosófica que tenho como ponto de partida, qual seja, aquela um dia protagonizada por Martin Heidegger, segundo a qual se manter na abertura do ser é um desafio ainda não vivido completamente. Assim, ao comentar ligeiramente algumas canções de Noel Rosa, não faço a mínima questão de dizer algo sobre elas que pareça definitivo, profundo ou inquestionável. Não é para esta direção que convergem os meus argumentos. Quero, contudo, sustentar que a articulação entre poesia e Filosofia que nelas ocorre - articulação que, em meu entendimento, é um modo de comparecer na abertura do ser - é condicionada por um compromisso do compositor com a vida. É desse compromisso que a canção retira o próprio vigor, tornando-se fonte constante para o pensamento.

Filosofia e poesia assemelham-se pelo menos em um aspecto: são manifestações de linguagem carregadas de uma irresistível vontade de dizer coisas que ultrapassam a temporalidade e a espacialidade cotidianas. Por isso, não é estranho que alguém de nosso convívio sinta-se representado nas palavras de um filósofo grego do século IV a.C. ou de um poeta inglês do século XVII. E também não causa surpresa o fato de muitas vezes não conseguirmos estabelecer o limite entre poesia e Filosofia em obras que desavisadamente supomos possuir um caráter específico; valham os exemplos dados por Nietzsche e Guimarães Rosa, dentre tantos. Certamente muitos recordam-se do início de textos como A Origem da Tragédia no Espírito da Música e Grande Sertão: Veredas. A que ordem pertenceriam expressões como uma estrela dançarina ou Nonada? E assim, como linguagens que visam ao extracotidiano, Filosofia e poesia coexistem com as manifestações de linguagem que dão ser à existência cotidiana, quais sejam, aquelas que servem à comunicação diária, às ciências e à própria Filosofia que se desdobra como técnica.

O fato é que a linguagem, seja ela poética, filosófica ou cotidiana, existe necessariamente entrelaçada à vida, expressando-a em suas divmensões, uma vez que efetiva- 
mente há a vida que é percebida como aspiração humana à transcendência, a exemplo daquela que, como história, perdura além dos indivíduos, e há outra, que ocorre no âmbito das temporalidades individuadas, seja de uma pessoa ou dos grupos historicamente e geograficamente situados. E é por isso também que as obras do espírito humano que se constituem ou que fazem uso de uma linguagem, tais como as obras de arte e a música, portam as marcas da vida em maior ou menor grau. Nas canções de Noel Rosa, a vida é vista em maior grau.

Se penso Filosofia e poesia na canção de Noel Rosa, é porque procuro vê-lo em sua mais completa inteireza. Quer dizer, considero-o na condição de sujeito, que esteve articulado à cultura, mas que também viveu em um estado de inconformidade com esta dimensão da existência. Presumivelmente, ele desejou ir além de suas experiências cotidianas, mesmo que não soubesse necessariamente para onde. Assim, ao pensá-lo como um compositor em particular, tenho como ponto de partida o ser humano em sua condição existencial genérica. ${ }^{2}$

Fatos históricos, conjunturais e pessoais são temas presentes nas canções de Noel Rosa dito cronista. Assim ocorreu já no seu primeiro sucesso, Com que roupa, ${ }^{3}$ em cuja letra se encontram referências a situações vivenciais e, sobretudo, referências à condição social de uma grande parcela da população urbana que, naquele momento, ficara marginalizada no processo de readequação do Brasil ao capitalismo internacional (SEVERIANO, 2008, p.135). Nesta mesma linha, inscreve-se Quem dá mais. ${ }^{4}$ Por outro lado, Pra que mentir ${ }^{5}$ e Último desejo ${ }^{6}$ referem-se claramente ao seu romance com a dançarina Ceci. Eu sei sofrer ${ }^{7}$ traz alusões ao estado de saúde ruim que levou o compositor à morte prematura; e assim multiplicam-se os exemplos.

Noel Rosa foi um homem de classe média que se aproximou das camadas urbanas populares, não apenas por simpatia ideológica, mas também por razões afetivas e estéticas. A propósito, sua crítica social é permeada pelo pensamento marxista, algo comum para uma parcela de jovens que tinha maior acesso aos bens culturais. Segundo Muniz Sodré, ele esteve entre os compositores que ajudaram a fazer o trânsito do êthos negro para a classe média, acolhendo desta maneira a ideologia do populismo nacionalista, ascendente em sua época. Não seria ele um cronista distanciado do objeto comentado, mas, diferentemente disso, ao falar, inscrever-se-ia em uma vivência cotidiana (SODRÉ,

\footnotetext{
2 Refiro-me aqui do conceito de vida fática (Dem faktischen Leben), tal como desenvolvido por Martin Heidegger (1988) no texto Ser e Tempo. Em resumo, o homem é o ente disposto no mundo como ser-aí (Dasein). Nesta condição, ele existe necessariamente interpretando a si mesmo e os entes circundantes, que são as suas próprias referências cotidianas. Observe que o ato de estar disposto no mundo interpretando-o é indissociável de uma compreensão (Verstehen) originária doada pelo ser que habita a linguagem. Por exemplo, podemos interpretar as coisas como obras de uma vontade divina, como decorrências de cadeias de causa e efeito, como frutos do acaso ou, ainda, podemos interpretá-las segundo qualquer outro modo desconhecido que vigore em alguma cultura em que estejamos inseridos (HEIDEGGER, 1988, p.188-195).
}

3 COM QUE roupa? Compositores: Noel Rosa, Rodrigo P. Martins, Eliseu Fiuza. Disponível em: https:/www.letras.mus.br/noel-rosa-musicas/125759/. Acesso em: 10 jun. 2021.

4 QUEM DÁ mais. Compositor: Noel Rosa. Disponível em: https://www.letras.mus.br/noel-rosa-musicas/542664/. Acesso em: 10 jun. 2021.

5 PRA QUE mentir? Compositor: Noel Rosa. Disponivel em: https:/www.letras.mus.br/noel-rosa-musicas/125753. Acesso em 10 jun. 2021.

6 ÚLTIMO desejo. Compositores: Noel Rosa e Vadico. Disponível em: https:/www.letras.mus.br/noel-rosa-musicas/125750/. Acesso: em 10 jun. 2021.

7 EU SEl sofrer. Compositor: Noel Rosa. Disponível em: https:/www.letras.mus.br/noel-rosa-musicas/1280541. Acesso em: 10 jun. 2021. 
1991, p.8). Noel interessava-se pela vida da cidade metaforizada na Vila Isabel, um espaço cultural de resistência, uma "cidade independente", tal como descrito em Palpite infeliz (SODRÉ, 1991, p.10). ${ }^{8}$

Como qualquer pessoa, Noel Rosa pertenceu ao seu tempo e sua ação esteve relacionada às suas próprias percepções. Foi justamente o seu modo de agir que o configurou como o artista que procuramos conhecer, estudando, sobretudo, a sua obra. Todavia, o que fez Noel Rosa para merecer de seu amigo Almirante a alcunha de filósofo do samba? O que pensam aqueles que concordam com isso? Fatos ou conjecturas certamente não capturam a totalidade da intuição nomeadora do Almirante. Poderia ele ter se referido a um modo de ser ou de expressar do compositor da Vila, ou, mais simplesmente ainda, a algumas de suas letras de temática filosófica (ALMIRANTE, 1977, p.119). A alcunha pegou a ponto de ser corroborada em textos da historiografia corrente, como os de Vasco Mariz (1996, p.125) e Jairo Severiano (2008, p.143).

Mas há mais em questão: algo que supõe o sentido abrangente do ato de filosofar, que ultrapassa em muito o dizer de palavras de cunho prescritivo ou ético, qual seja, o sentido de ser aquele pensamento que é capaz de pensar a si mesmo. ${ }^{9} \mathrm{E}$ tenho comigo que é assim que a Filosofia comparece na canção de Noel Rosa, para então poder cumprir a exigência da angústia que decorre de sua própria situação existencial. É sobre isso que penso ao escrever o presente texto. Para tanto, olho inicialmente para a articulação mais ampla entre ser humano e vida, considerando, evidentemente, que o compositor participe dela.

A narrativa que se constitui em torno de Noel Rosa se fundamenta em relatos, testemunhos da época e textos poéticos que muitas vezes reforçam ou permitem fantasiar o que foi dito alhures. É por isso que a historiografia não reluta em identificar traços biográficos em suas canções. Todavia, tais fontes, por si só, pouco revelam sobre a angústia que o desperta para as questões filosóficas. De onde provém a estranheza que o desloca para fora da afinação vigorante ${ }^{10}$ De onde vem a sua própria poesia? Diz-se que há um Noel Rosa otimista e outro pessimista (SEVERIANO, 2008, p.135). Certamente esses e outros estados de ânimo possuem relações com situações vividas, mas ao filósofo, assim como ao compositor, é permitido ser indiferente.

\footnotetext{
8 PALPITE infeliz. Compositores: Noel Rosa e Maurício M. Carvalho. Disponível em: https:/www.letras.mus.br/noel-rosa-musicas/397352/. Acesso em: 10 jun. 2021.

9 A reflexividade da Filosofia é pensada, dentre outros modos, nas três críticas kantianas (Crítica da Razão Pura, Crítica da Faculdade do Juízo, Crítica da Razão Prática) e também na Hermenêutica de Martin Heidegger, que leva o pensamento em direção aos seus fundamentos histórico-ontológicos.

10 Em sua Analítica do Dasein (Ser e Tempo), Heidegger sugere que a nossa maneira de interpretar e compreender o mundo é revestida por uma tonalidade afetiva (Stimmung) compartilhada (HEIDEGGER, 2007, p.92). Quer dizer, vivemos sob um patamar de concordância com um modo histórico de ser no mundo, algo que nos aproxima, mas que muitas vezes nos deixa alienados de nós mesmos para, simplesmente, sermos com e como os outros (Das Man) (HEIDEGGER, 2003, p.194). Esta tonalidade afetiva, também justamente denominada afinação, é desapercebida por aqueles que, cotidianamente, dela compartilham. Por isso, pode parecer natural pensar coletivamente sob a direção de um ou de outro modo do ser. Provavelmente esse é um elemento que provoca o estreitamento dos laços intersubjetivos, fundamentais à gênese e à permanência da cultura (HEIDEGGER, 1988, p.97). Um modo do ser aparentemente natural é o que provém da compreensão de que os entes são utensílios, que se articulam segundo uma finalidade dentro de uma ordem inteligivel. Em uma palavra, dizer o que uma coisa é torna-se o mesmo que dizer a finalidade que ela cumpre numa suposta totalidade estruturada por relações de causa e efeito. Destarte, igualamo-nos sob a compreensão compartilhada de que somos uma comunidade de úteis, o que é válido para os seres humanos, para as coisas e para tudo mais que existe.
} 
Observa Sodré (1991, p.11) que "Noel reivindicava a filosofia como uma atitude para a convivência com regime de exclusão do povo e com o liberalismo político que não passava de uma paródia da democracia representativa: 'Mas a filosofia / Hoje me auxilia / A viver indiferente'"'.11 Não discordando deste autor, penso que também é válido conjecturar por que outro motivo a filosofia é vista como algo que traz a atitude da indiferença. Poderia ela estar sendo compreendida como um recurso de escapismo ou mesmo de supressão do valor da realidade? É plausível. Porém, podemos pensar que a Filosofia provoca a indiferença justamente por inscrever a estranheza do extracotidiano na ordem cotidiana. Neste caso, ser indiferente não é propriamente escapismo, mas, na verdade, um modo de superação.

Ocorre-me o célebre argumento cínico de Sócrates, para quem a razão não contraditória ensina que diante da morte temos duas possibilidades: ou a paz alcançada pela aniquilação da existência ou a eternidade na vida após a morte (PLATÃO, 2011, p.143). Nesse caso, a razão (Filosofia) tranquiliza o ser humano diante do motivo radical de sua angústia, qual seja, a possibilidade inexorável da morte. Entretanto, eis o que parece mais relevante a Sócrates: a razão é o instrumento para a ascese da alma. Quer dizer, estando ou não faticamente mergulhados na mediocridade da existência, a alma transforma-se com a ciência do fato novo que não propriamente está em conformidade com a aparência do sensível.

$\mathrm{Na}$ condição de seu próprio sujeito, Noel Rosa afirmou desesperadamente a vida, mesmo que isso tenha significado um movimento inequívoco em direção à morte. Seja por suas atitudes cotidianas, seja por sua produção poética (Poiesis), buscou incessantemente a diferença, inclusive na indiferente Filosofia, como se na vida que ele resumiu em poucos anos não houvesse tempo para ser fútil. É assim que ele trouxe a Filosofia para as suas canções, tornando-a nelas presente em dois modos. Em um primeiro, mais facilmente reconhecível, ela aparece como referência textual a algumas de suas vertentes, temas e teses. Em um segundo modo, ela está na radical e legítima relação entre palavra e vida.

Tomo, como exemplo, a poética condensação de significados em Positivismo. ${ }^{12}$ As teses nela referidas não são propriamente apresentadas; antes, porém, elas são desconstruídas dentro de uma linguagem poética que quer ter a aparência de linguagem cotidiana: "A verdade, meu amor, mora num poço". Recorrendo a esta imagem corriqueira, Noel Rosa refuta as tradicionais concepções sobre a verdade; a saber, ela está no poço, não na adequação da proposição (adaequatio rei et intelectus) ou no arbítrio do sujeito, como querem

\footnotetext{
11 FILOSOFIA. Compositores: Noel Rosa; André Filho. Disponível em: https:/www.letras.mus.br/noel-rosa-musicas/125751/. Acesso em: 10 jun. 2021.

12 Positivismo (Noel Rosa e Orestes Barbosa): A verdade, meu amor, mora num poço / É Pilatos lá na Bíblia quem nos diz / Que também faleceu por ter pescoço / O autor da guilhotina de Paris / A verdade, meu amor, mora num poço / É Pilatos lá na Bíblia quem nos diz / Que também faleceu por ter pescoço / O infeliz, autor da guilhotina de Paris / / Vai orgulhosa querida / Mas aceita esta lição / No câmbio incerto da vida / A libra sempre é o coração / $\mathrm{O}$ amor vem por princípio, a ordem por base / O progresso é que deve vir por fim / Desprezaste esta lei de Auguste Comte / E foste ser feliz longe de mim / $O$ amor vem por princípio, a ordem por base / $O$ progresso é que deve vir por fim / Desprezaste esta lei de Auguste Comte / E foste ser feliz longe de mim // Vai, coração que não vibra / Com seu juro exorbitante / Transformar mais outra libra / Em dívida flutuante / A intriga nasce num café pequeno / Que se toma para ver quem vai pagar / Para não sentir mais o teu veneno / Foi que eu já resolvi me envenenar. Disponivel em: https://www.letras.mus.br/noel-rosa-musicas/1002911/. Acesso em: 10 jun. 2021.
} 
as filosofias clássica e moderna, respectivamente. Por conseguinte, a verdade não sustenta a ordem suposta pelo Positivismo ou por qualquer outra filosofia, poderíamos inferir, posto que está deslocada de sua geografia e de sua posição no pensamento.

Se a verdade é um fundamento que está no poço, temos o fracasso de tudo que ele sustenta; o fracasso da vida amorosa de um sujeito, da ética de uma sociedade, da economia de um país que tem o valor relativo de sua moeda diminuído pela ação especulativa, o fracasso, sobretudo, da Filosofia que pretende orientar todas essas dimensões da vida. ${ }^{13}$ Talvez por isso, a autoridade invocada por Noel Rosa para dar continuidade ao discurso não é nenhum filósofo ou grande profeta, mas, simplesmente, Pilatos, célebre no imaginário cristão por seu pragmatismo e pusilanimidade. E foi esse vulto da antiga história de Roma, segundo licença poética, quem nos contou sobre a irônica situação vivida pelo inventor da guilhotina, que, séculos depois, teria sido executado em seu invento. ${ }^{14}$

Em Positivismo as dimensões da vida estão profundamente imbricadas. $O$ fato pessoal da desilusão amorosa coexiste com o desmascaramento de um projeto político, econômico e ético excludente. E então o compositor não se furta de subverter o lema que está estampado na bandeira do Brasil: "O amor vem por princípio, a ordem por base / O progresso é que deve vir por fim / Desprezaste esta lei de Auguste Comte / E foste ser feliz longe de mim". Nesse mundo cuja ordem escapa a qualquer projeto idealista, nesse mundo destituído do fundamento da verdade, mantém-se quem, contrariando o niilismo, cultiva a própria força: "A intriga nasce num café pequeno / Que se toma para ver quem vai pagar / Para não sentir mais o teu veneno / Foi que eu já resolvi me envenenar". Nesses versos, a referência ao "além-homem" nietzscheano parece inequívoca e está em absoluto acordo com o tom irônico do texto: "Alguma vez um dragão morreu do veneno de uma serpente?" (NIETZSCHE, 2012, p.65).

Ao realizar a crônica de um sujeito que ele quer incluir na sociedade urbana, Noel Rosa transmuta a Filosofia em linguagem cotidiana, fazendo com que ela dê voz aos desejos e contradições humanas. É assim, por exemplo, que o pobre pode experimentar a condição de senhor, mesmo que no espaço e no tempo próprios da canção, onde ocorre uma provocante conversa de botequim: "Telefone ao menos uma vez / Para três-quatro-quatro-três-três-três / E ordene ao seu Osório / Que me mande um guarda-chuva / Aqui pro nosso escritório / Seu garçom me empresta algum dinheiro / Que eu deixei o meu com o bicheiro / Vá dizer ao seu gerente / Que pendure esta despesa / No cabide ali em frente". ${ }^{15}$

Mas o que permite a Noel Rosa transmutar a Filosofia em linguagem cotidiana é a poesia. Pois é justamente a poesia que dá valor de verdade ao texto e, por conseguinte, às si-

\footnotetext{
13 Ao assim pensar, Noel Rosa coloca-se em consonância com a filosofia de seu tempo, caracterizada, sobretudo, pela crítica radical à linguagem e, consequentemente, a todos os fundamentos da metafísica. É o que se pode ver em obras paradigmáticas, tais como o Tractatus lógico-philosophicus de Ludwig Wittgenstein (1889-1951) e Os fundamentos da aritmética de Friedrich Ludwig Gottlob Frege (1848-1925).

14 "Que também faleceu por ter pescoço / O autor da guilhotina de Paris". Neste caso, Noel Rosa reproduziu um equívoco histórico. O inventor da guilhotina foi o médico Joseph-Ignace Guillotin (1738-1814), que morreu de morte natural.

15 CONVERSA de Botequim. Compositores: Noel Rosa e Vadico. Disponível em: https://www.letras.mus.br/noel-rosa-musicas/125756/. Acesso em: 10 jun. 2021.
} 
tuações inusitadas que ele possa descrever. Ressalto a sentença sugerida, "a poesia dá valor de verdade ao texto"; isso tem a ver com a credibilidade da canção, com a capacidade que ela tem de estabelecer-se como um objeto autônomo que, ao destacar-se da generalidade dos outros objetos, oferece suas próprias experiências. ${ }^{16}$ É por isso que, no universo da canção de Noel Rosa, o pensamento pode experimentar outras proposições de realidade que não sejam aquelas impostas pelas relações de produção e poder, fato que, inclusive, dá profundidade à crítica social elaborada pelo compositor cronista.

Em sua canção, Noel Rosa faz parecer cotidiano o que é extracotidiano. É assim que ele inclui todos aqueles excluídos da sociedade, promovendo-os ao patamar de humanidade que lhes foi historicamente subtraído. Se isso é evidente nas referências de sua crônica, é, no entanto, mais profundo na poesia que requalifica as palavras. Através dela, o pensamento é revestido da credibilidade da opinião comum, que, em contrapartida, deixa de ser tão comum assim, posto que a poesia tem em sua própria essência o melos, que também é essência do samba.

$E$, se o melos da palavra está em solidariedade com o melos do samba, tudo é um lógos só, pelo qual música e palavra intercambiam acentuações métricas, ritmos e inflexões. ${ }^{17}$ Esse fato torna qualquer distinção entre música e letra artificial e fantasiosa. Nesse sentido, o exemplo oferecido pela canção Gago apaixonado é bastante eloquente: "Mu-mu-mulher, em mim fi-fizeste um estrago / Eu de nervoso estou-tou fi-ficando gago / Não po-posso com a cru-crueldade da saudade / Que que mal-maldade, vi-vivo sem afago / Tem tem pe-pena deste mo-moribundo / Que que já virou va-va-va-va-ga-gabundo...".18

Não importa se a música do samba foi composta por Noel Rosa ou algum de seus parceiros, pois ela forma um único organismo com a palavra. Assim, o samba que é do compositor é o mesmo samba que é lógos de muitos, justamente das populações dos negros marginalizados em uma cultura, para a qual eles conferem identidade. Um samba de linguagem harmônica límpida, consonante, que caminha desembaraçadamente por acordes invertidos, sem roubar do ouvinte a atenção que a palavra requer. Enfim, um samba cujo

\footnotetext{
16 A propósito, a tese heideggeriana sobre a verdade é revolucionária: a arte é um local do acontecimento da verdade (alétheia)! Quer dizer, a verdade não estaria no sujeito ou nas coisas, como correntemente pensado na história da Filosofia; diferentemente disso, seria ela um acontecimento em uma região do ente, onde matéria e forma não se sintetizariam para cumprir uma finalidade. A esta região, Heidegger denomina clareira (Lichtung), aludindo precisamente ao clarão (der Riss) que nela seria produzido pela tensão constante entre matéria e forma, que, por sua vez, tornar-se-iam visíveis em si mesmas em função da própria claridade que produziam (HEIDEGGER, 1977, p.117). 0 diálogo entre Heidegger e Aristóteles é evidente. Heidegger abre um parêntese na determinação do ser proposta por Aristóteles, em sua Doutrina das Quatro Causas. Particularmente, Heidegger esteve atento ao caráter finalista desta determinação, porquanto seja: uma matéria (causa material), sob a ação de uma força motriz (causa eficiente), adquire uma forma (causa formal) para cumprir uma finalidade (causa final) (ARISTÓTELES, 1931, p.190a-192b). Ao apontar para a existência de entes que escapam a essa lógica - precisamente os fenômenos artísticos -, Heidegger incluiu a possibilidade do extracotidiano na totalidade inteligível. Seria a arte estranha aos entes cotidianos devido ao que nela acontece: a verdade que dá abertura para a indeterminação do ser; quer dizer, ela dá abertura ao impensado, ao não casual dentro da casualidade, às outras tonalidades afetivas além daquelas que foram historicamente experimentadas. E o que Heidegger diz para as artes plásticas e para a poesia diz muito mais para a música.

17 Na perspectiva de Martin Heidegger, a música é lógos, isto é, ela é portadora da tensa concordância entre a matéria e a forma - o aspecto do ente em sua primeira acepção. É melos: uma síntese incompleta entre som e imagem, como uma palavra de significantes puros, apta a colher todos os significados latentes. A música é então a quietude proveniente de uma relação de concordância discordante. É a consonância do quieto, o estado mais íntimo da escuta que apreende a música das coisas e da linguagem e que promove a reunião unificadora da identidade e da diferença. É lógos da palavra e da dança (mousiké), é a afinação (Harmonié) que dá a tonalidade afetiva ao mundo circundante (HEIDEGGER, 2003, p.24-26). A música é, portanto, em si mesma extraordinária.
}

18 GAGO apaixonado. Compositor: Noel Rosa. Disponível em: https://www.letras.mus.br/noel-rosa-musicas/125755/. Acesso em: 10 abr. 2021. 
próprio lógos é a marca física da presença do sujeito histórico que o canta.

A tonalidade afetiva aberta pelo samba sustenta significados inesperados. Atento às primeiras palavras de Mão no Remo: "Nesta vida, nesta vida cada qual / Tem um barco em que navega / E o azar é natural / Nem há nada mais fatal / E a justiça é cega". ${ }^{19}$ Aqui ocorre mais uma expressiva condensação poética de significados; a temática do trágico vem à tona por meio da referência à inexorabilidade do destino, metaforizado na imagem do barco, para o qual o "azar", e não a "sorte", é "natural" e "fatal". Quer dizer, cada um tem seu "azar", e não sua "sorte", nessa espécie de releitura pessimista do mito das Moiras. E esse fato inexorável que diz respeito a toda humanidade é legitimado por uma "justiça cega", que, tendo em conta os versos seguintes, não considera em seu julgamento os percalços individuais; o amor cotidiano, que diz respeito às individualidades e conjunturas, está sujeito a uma lei mais forte contra a qual lutamos, qual seja, o destino.

Mão no Remo não é a única canção em que a temática filosófica é associada ao tema do amor cotidiano. Para não me alongar em exemplos, basta ler as letras de Positivismo, já mencionada neste texto, Feitio de Oração e Silêncio de um minuto, dentre outras. Entendo que esta associação entre Filosofia e amor é uma estratégia estilística eficaz com que Noel Rosa aproxima o extracotidiano do cotidiano. Esta aproximação, por sua vez, é emocionalmente sustentada quando, por alguma feliz coincidência, o poema de teor trágico combina com a música de clima exaltador, tal como, em nossa cultura, aprendemos a ouvir a música de Ary Barroso, parceiro de Noel Rosa na referida canção.

E, se o samba parecer feliz por demais em relação ao texto que sustenta, é devido à sua natureza. Pois é assim, dando voz sincopada à sensualidade, que ele pode se afirmar como expressão da força e resistência corporal de um povo. Com todo o respeito e admiração que tenho por Vinicius de Moraes, não sei se "o samba é a tristeza que balança"20 ou se é a própria tristeza que nele se dissolve. E, quando o samba traz a Filosofia para dentro de si, subtraindo-a ao império de uma razão que se pretende pura, ele a coloca no patamar de um pensamento que dialoga com a angústia das pessoas comuns.

Feitio de oração; ${ }^{21}$ quer dizer, o samba tem o aspecto físico de uma oração ou, como quer Vinicius de Moraes em seu Samba da Benção, ele é "uma forma de oração" para recorrer nas situações de uma vida que é a "arte do encontro, embora haja tanto desencontro". Nesse caso, uma canção revigora a outra e entre elas há algo que se mantém, precisamente, a ideia de que a oração é o caminho mais reto que nos leva ao objeto almejado. E não se trata de qualquer objeto, pois, se "quem acha vive se perdendo", é preciso encontrar-se a si mesmo na relação com o outro. Entretanto, para uma tal busca não há ponto de partida mais seguro que o coração, posto que o que se procura está na imediatez ambígua ou mesmo confusa dos sentimentos: "sambar é chorar de alegria".

19 MÃO NO Remo (iça A Vela). Compositores: Noel Rosa e Ary Barroso. Disponível em: https://www.letras.mus.br/noel-rosa-musicas/1284002/. Acesso em: 10 jun. 2021.

20 Refiro-me evidentemente ao Samba da Benção (Vinicius de Moraes e Baden Powell): Disponivel em: https:/www.letras.mus.br/vinicius-de-moraes/86496/. Acesso em: 10 jun. 2021.

21 FEITIO de Oração. Compositores: Noel Rosa e Vadico. Disponível em: https://www.letras.mus.br/noel-rosa-musicas/535516/. Acesso em: 16 abr. 2021. 
Assim, caracterizado como oração, o samba não pode ser de um lugar da cidade, marcado pela lógica segregadora da sociedade de classes, ${ }^{22}$ muito menos pode ser aprendido em uma instituição de ensino. Antes disso, ele é aprendido no estado de passividade do apaixonado, justamente porque vem de um lugar que presumivelmente antecede a ação de uma razão calculadora que para muitos organiza o mundo, assim fala o mais schopenhaueriano dos "Noéis": "O samba na realidade não vem do morro / Nem lá da cidade / E quem suportar uma paixão / Sentirá que o samba então / Nasce do coração". ${ }^{23}$ Menciono por fim aquela que é correntemente apontada como a mais filosófica canção de Noel Rosa: Silêncio de um minuto (SEVERIANO, 2008, p.143). ${ }^{24}$ Afora todas as considerações feitas sobre as referências de ordem pessoal constantes no texto, detenho-me apenas no que ele aparentemente diz na tonalidade afetiva de um samba-canção; primeiro, a definição de morte como ausência do outro diante dos sentidos: "Não te vejo e nem te escuto", posto que a única experiência concreta que temos em relação à morte é a percepção da ausência do outro. A propósito, assim compreendo as palavras de Heidegger (1988, p.250): a morte é uma experiência impessoal, uma vez que em vida não a conhecemos, apenas sabemos dela indiretamente, pela morte de um conhecido ou ente querido, e há até um certo gozo nisso.

Considerado este caráter de impessoalidade da morte, observo que quem está de luto não é o sujeito que fala na canção, mas o samba, justamente, a linguagem que intermedeia a sua relação com o mundo. Nesse sentido, parece-me bastante adequada a interpretação da canção na voz da Aracy de Almeida; nela há um comedimento na expressão da dor que muito combina com o afeto produzido pela orquestração e condução sincopada da música. De algum modo esse comedimento expressa a relativa distância entre sujeito e experiência. ${ }^{25}$

Entretanto, a deferência ao luto é feita: "Eu peço o silêncio de um minuto...". Justamente o silêncio, que também é entendido como ausência da manifestação sonora de um ente diante dos sentidos (RODRIGUEZ, 2006, p.185). É assim que, na proximidade do texto de Noel Rosa, morte e silêncio possuem um parentesco semântico. Todavia, a que morte ambos aludem? Precisamente, não à morte de uma pessoa, mas à morte de um amor: "De um amor cheio de glória / que me pesa na memória". E se um enterrou esse amor com a "pá do fingimento", o outro o chora indiretamente, por intermédio do violão.

Na canção Silêncio de um minuto as coisas e os próprios sentimentos estão animados ou mesmo substantivados, de modo a incorporarem os sentimentos e os qualificativos humanos. Há, portanto, uma inversão na ordem dos acontecimentos; não são

\footnotetext{
22 É pertinente a interpretação de Carlos Sandroni para esta canção. Ele entende que nela ocorre uma discussão sobre a origem do samba e do Brasil, tal como na Semana de 22; o samba não seria do morro ou da cidade, mas do coração (SANDRONI, 2001, p.174).

23 A menção a Schopenhauer é pontual. É corrente o reconhecimento de que esse filósofo tem no seu projeto a crítica radical e violenta à metafísica, sobretudo no que concerne à postulada necessidade de libertar os sentidos do jugo da razão calculadora. Não é preciso ser um leitor muito atento para depreender isso da leitura de 0 mundo como vontade e representação.

24 SILÊNCIO de um minuto. Compositor: Noel Rosa. Disponivel em: https://www.letras.mus.br/noel-rosa-musicas/1351694/. Acesso em: 10 jun. 2021.
}

25 Disponível em: https://www.letras.mus.br/noel-rosa-musicas/1351694/. Acesso em: 10 jun. 2021. 
as pessoas que se reificam, mas são as coisas que se humanizam, a ponto, inclusive, de subverterem o imperativo racista que permeia nossa sociedade: "Que o meu samba está de luto / Meu violão vai soluçar / Luto preto é vaidade / Neste funeral de amor / O meu luto é saudade / E saudade não tem cor". Dado o que foi dito, mais uma vez, a partir da licença para a significação aberta pela poesia, a Filosofia pode estabelecer-se em sua indiferença e realizar a crítica radical das situações que angustiam um ser humano, sobretudo as situações em que ele se depara com a perda ou naquelas situações em que pressente a perda de si mesmo na prometida morte.

A canção de Noel Rosa é, portanto, a história do produto de uma sensibilidade aguçada que retira poesia e Filosofia dos altares do julgamento, devolvendo tais expressões à origem, onde o ser humano experimenta a vida com seus instrumentos mais próximos. Nada de muito grandioso ou espetacular, apenas um brilho de joia que dá singularidade às impressões existentes. E, se em algum momento me propus a falar da canção de Noel Rosa, talvez mais tenha falado para as coisas que ela inadvertidamente dá voz, e, certamente, poesia e Filosofia estão entre elas, ainda que sob o pretexto do amor e dos problemas cotidianos. É assim que a canção, em sua singela finitude, dá aparência de infinitude ao mundo que a contém.

\section{Referências}

ALMIRANTE. No tempo de Noel Rosa. Rio de Janeiro: Francisco Alves, 1977.

ARISTÓTELES. Physique. Paris: Les Belles Lettres, 1931.

ARISTÓTELES. Metafísica. São Paulo: Loyola, 2002.

COM QUE roupa? Compositores: Noel Rosa, Rodrigo P. Martins, Eliseu Fiuza.

Disponível em: https://www.letras.mus.br/noel-rosa-musicas/125759/. Acesso em:

10 jun. 2021.

CONVERSA de Botequim. Compositores: Noel Rosa e Vadico. Disponível em: https:// www.letras.mus.br/noel-rosa-musicas/125756/. Acesso em: 10 jun. 2021.

DILTHEY, Wilhelm. Teoria das Concepções de Mundo. Lisboa: Ed. 70, 1992.

EU SEl sofrer. Compositor: Noel Rosa. Disponível em: https://www.letras.mus.br/noel-rosamusicas/1280541. Acesso em: 10 jun. 2021.

FEITIO de Oração. Compositores: Noel Rosa e Vadico. Disponível em: https://www.letras. mus.br/noel-rosa-musicas/535516/. Acesso em: 10 jun. 2021.

FILOSOFIA. Compositores: Noel Rosa e André Filho. Disponível em: https://www.letras. mus.br/noel-rosa-musicas/125751/. Acesso em: 10 jun. 2021. 
FREGE, Friedrich Ludwig Gottlob. Os fundamentos da aritmética. Disponível em: https:// marcosfabionuva.files.wordpress.com/2011/08/os-fundamentos-da-aritmc3a9tica.pdf. Acesso em: 10 jun. 2021.

GAGO apaixonado. Compositor: Noel Rosa. Disponível em: https://www.letras.mus.br/noelrosa-musicas/125755/. Acesso em: 10 jun. 2021.

HEIDEGGER, Martin. A Origem da Obra de Arte. Lisboa: Ed. 70, 1977.

HEIDEGGER, Martin. Ser e Tempo. Rio de Janeiro: Vozes, 1988.

HEIDEGGER, Martin. A Caminho da Linguagem. Rio de Janeiro: Vozes, 2003.

HEIDEGGER, Martin. Metafísica de Aristóteles. Petrópolis: Vozes, 2007.

MÃO NO Remo (iça A Vela). Compositores: Noel Rosa e Ary Barroso. Disponível em: https://www.letras.mus.br/noel-rosa-musicas/1284002/. Acesso em: 10 jun. 2021.

MARIS, Vasco. A canção brasileira. Rio de Janeiro: Francisco Alves, 2002.

MORAES, Vinicius; POWELL, Baden. Samba da Benção. Disponível em https://www.letras. mus.br/vinicius-de-moraes/86496/. Acesso em: 10 jun. 2021.

NIETZSCHE, Friedrich. Assim falou Zaratustra. São Paulo: Martin Claret, 2012.

PALPITE infeliz. Compositores: Noel Rosa e Maurício M. Carvalho. Disponível em: https://www.letras.mus.br/noel-rosa-musicas/397352/. Acesso em: 10 jun. 2021.

PLATÃO. Fédon. Belém: Ed. UFPA, 2011.

POSITIVISMO. Compositores: Noel Rosa e Orestes Barbosa. Positivismo. Disponível em: https://www.letras.mus.br/noel-rosa-musicas/1002911/. Acesso em: 10 jun. 2021.

PRA QUE mentir? Compositor: Noel Rosa. Disponível em: https://www.letras.mus.br/noelrosa-musicas/125753. Acesso em: 10 jun. 2021.

QUEM DÁ mais. Compositor: Noel Rosa. Disponível em: https://www.letras.mus.br/noelrosa-musicas/542664/. Acesso em: 10 jun. 2021.

RODRIGUEZ, Ángel. A dimensão sonora da linguagem audiovisual. São Paulo: Editora Senac, 2006. 
SANDRONI, Carlos. Feitiço Decente: transformação do samba no Rio de Janeiro (19171933). Rio de Janeiro: Jorge Zahar, 2001.

SCHOPENHAUER, Arthur. O mundo como vontade e representação. São Paulo: UNESP, 2015.

SEVERIANO, Jairo. Uma história da música popular brasileira: das origens à modernidade. São Paulo: Editora 34, 2008.

SILÊNCIO de um minuto. Compositor: Noel Rosa. Disponível em: https://www.letras.mus. br/noel-rosa-musicas/1351694/. Acesso em: 10 jun. 2021.

SODRÉ, Muniz. A lira independente. In: CHEDIAK, Almir. Songbook Noel 3. Rio de Janeiro: Lumiar, 1991. p. 8-11.

ÚLTIMO desejo. Compositores: Noel Rosa e Vadico. Disponível em: https://www.letras. mus.br/noel-rosa-musicas/125750/. Acesso em: 10 jun. 2021.

WITTGENSTEIN, Ludwig. Tractatus logico-philosophicus. São Paulo: Edusp, 2001. 